\title{
Narratives of young people on same-sex relationships about their path and implications for mental health
}

\author{
Relatos de jovens homoafetivos sobre sua trajetória e implicações para a saúde mental
}

Historias de jóvenes homoafectivos sobre su trayectoria e implicaciones para la salud mental

\author{
Andréa Noeremberg Guimarães ${ }^{1}$ \\ Gabriel Deolinda da Silva de Marqui ${ }^{1}$ (C) \\ Maria Luiza Bevilaqua Brum ${ }^{1}$ (C) \\ Carine Vendruscolo ${ }^{1}$ (it) \\ João Marcos Werner ${ }^{1}$ \\ Elisangela Argenta Zanatta ${ }^{1}$
}

1. Universidade do Estado de Santa Catarina.

Chapecó, SC, Brasil.

\section{Abstract}

Objective: To know the life path of young people in same-sex relationship from the discovery of their sexual orientation and the confrontation of problems arising from it, contextualizing situations that affect their mental health and reflect on the role of nursing in care, within the scope of Primary Health Care. Method: Qualitative research performed in two public institutions of higher education. Nineteen homoaffective young people participated in the interviews, following a script with open questions related to mental health and same-sex relationship. Data interpretation used the content analysis. Current ethical precepts have been respected. Results: The difficulties of youth concerning the discovery and acceptance of homoaffectivity are related to confrontations in the familiar coexistence and with social groups, cultural and religious aspects. Conclusion and implications for practice: This issue provokes reflections in the nursing professionals concerning the mental health care practices, considering the cultural competence in the Primary Care scope.

Keywords: Nursing Education; Mental Health; Homosexuality; Primary Health Care.

\section{RESUMO}

Objetivos: Conhecer a trajetória de jovens homoafetivos(as) a partir da descoberta da sua orientação sexual e do enfrentamento de problemas decorrentes, contextualizando situações que afetam sua saúde mental e refletir sobre o papel da enfermagem no cuidado, no âmbito da Atenção Primária à Saúde. Método: Pesquisa qualitativa, realizada em duas instituições públicas de ensino superior. Foram realizadas entrevistas com 19 jovens homoafetivos, seguindo roteiro com questões relativas à saúde mental e homoafetividade. A interpretação das informações seguiu os passos da análise de conteúdo. Foram respeitados preceitos éticos vigentes. Resultados: As dificuldades dos jovens em relação à descoberta e aceitação da homoafetividade estão relacionadas com enfrentamentos no convívio familiar e com grupos sociais, aspectos culturais e religiosos. Conclusão e implicações para a prática: $O$ tema provoca reflexões nos profissionais de enfermagem sobre as práticas de cuidado à saúde mental dessa população, considerando a competência cultural no âmbito da Atenção Primária.

Palavras-chave: em Enfermagem; Saúde Mental; Homossexualidade; Atenção Primária à Saúde.

\section{REsumen}

Objetivo: Conocer la trayectoria de jóvenes homoafectivos a partir del descubrimiento de su orientación sexual y enfrentamiento de problemas derivados, contextualizando situaciones que afectan su salud mental; y reflexionar sobre el papel de la enfermería en el cuidado, según la Atención Primaria en Salud. Método: Investigación cualitativa, realizada en dos instituciones públicas de enseñanza superior. Diecinueve jóvenes homoafectivos participaron de las entrevistas, siguiendo un guía con cuestiones abiertas relativas a salud mental y homoafectividad. Interpretación de datos según el análisis de contenido. Los preceptos éticos vigentes fueron respetados. Resultados: Las dificultades de los jóvenes delante del descubrimiento y aceptación de la homoafectividad se relacionan con enfrentamientos en la convivencia familiar y con grupos sociales, aspectos culturales y religiosos. Conclusión e implicaciones para la práctica: El tema provoca reflexiones en los profesionales sobre prácticas de atención a la salud mental de esa población, considerando la competencia cultural de la Atención Primaria.

Palabras clave: Educación en Enfermería; Salud Mental; Homosexualidad; Atención Primaria de Salud.
Corresponding author

Andréa Noeremberg Guimarães.

E-mail: andrea.guimaraes@udesc.br.

Submitted on $08 / 10 / 2018$

Accepted on 12/01/2018.

DOI: 10.1590/2177-9465-EAN-2018-0240 


\section{INTRODUCTION}

Same-sex relationships have already been considered a mental disorder, criminal offense and violation of traditional cultural values in many countries. Over the years, there have been social transformations and gradual changes in its concept. However, the social acceptance of people with this sexual orientation is still low and there are unilateral opinions and negative attitudes regarding this issue. ${ }^{1}$ As a consequence, people with homoaffective orientation end up experiencing additional stressors in daily life, in all environments, such as situations of prejudice, internalized homophobia and expectations of rejection, causing harm to their health. ${ }^{2} \mathrm{~A}$ study carried out with young people that experienced same-sex relationship revealed that this population has been the victim of different types of physical, verbal, psychological and sexual violence, as well as suicide attempts, and that the school, the family and the community are the main scenarios in which homophobia occurs. Physical violence was not so frequent when compared to verbal and psychological violence, however, it is more frequent against male homosexual adolescents. ${ }^{3}$ Studies ${ }^{2,4-8}$ add that as a result, compared to the general population, homosexuals have a higher prevalence of mental health problems, including anxiety, depression, suicidal ideation and suicide attempts. They also present a higher prevalence of health risk behaviors, such as high alcohol use, marijuana and daily smoking. ${ }^{9}$

In Brazil, the "Programa Brasil Sem Homofobia" ("Brazil Without Homophobia Program", in free translation) and the "Policy of Integral Assistance to the Health of the Lesbian, Gay, Bisexual, Transsexual and Transgender (LGBT) ${ }^{10}$ population" were instituted in order to contribute to the reduction of this problem. In this acronym, currently, the letter I was added, becoming LGBTI, after the increasing growth of intersex people.

The position of the federal government, until then, has marked the defense of the LGBTI community by offering spaces to denounce prejudice and inserted the speech "if you feel threatened, call us!", "if you suffer or witness some kind of violence or discrimination, denounce!" and "call 100", indicating the concern with any form of violence, aiming at the construction of a more just society. ${ }^{10}$ However, more recently, with the economic, political and cultural crisis that affects the country, violence and prejudice towards people who experience same-sex relationship have sometimes been encouraged.

Faced with this reality, the motivation to investigate the trajectory of young people who experience same-sex relationship emerges from the attentive observation and sensitization, as professionals, students and researchers in the nursing area, about the need to instrumentalize health professionals, especially nurses, to caring for individuals and populations susceptible to psychic suffering related to their sexual orientation, familiarizing them with the different faces of this problem, so that they feel safe for interventions. We want to understand how is developed the process of discovering / accepting oneself homoaffective, as well as the recurrent confrontations of walking the life, before family, friends and society. It is worth noting that the scientific literature is sparse of materials on this subject, especially in the area of mental health nursing and Primary Health Care $(\mathrm{PHC})$, the main entry point of the Unified Health System (UHS) and, therefore, space where meetings take place, among professionals, health students and users and, therefore, common locus of identifying the problems of life in families and communities. Thus, this study becomes important because it may contribute to nursing professionals' reflection on mental health care practices for this population and its vulnerabilities, in view of the strengthening of the $\mathrm{PHC}$ model in Brazil that relates to social inclusion based on the notion of "health for all", inscribed in agendas such as Alma-Ata. In addition, it proposes the echoing shout in the search for formal inclusion of this population, facing the social diversity and taking into account the attribute derived from the $\mathrm{PHC}$ that has to do with its cultural competence.

It should also be pointed out that research on the mental health of vulnerable people, whatever the reason, needs to be carried out in order to collaborate with knowledge that may lead to the prevention and development of effective interventions, since understanding the mental health needs of the LGBTI population is not only a question of public health but also of human rights. ${ }^{4}$

Thus, the objectives of this study were to know the trajectory of homoaffective young people from the discovery of their sexual orientation and the confrontation of problems, contextualizing situations that affect their mental health and to reflect on the role of nursing in the care, in the scope of Primary Health Care.

\section{METHOD}

This is a qualitative, descriptive research carried out in two public higher education institutions in Santa Catarina. Nineteen homoaffective young people, who were included in the inclusion criteria, participated in the study. Inclusion criteria: to be a student enrolled in a graduation course in the period of information collection; to self-declare in a same-sex relationship, regardless of sex; be over 18 years of age; and be up to 24 years old, maximum age that includes the classification of young according to the World Health Organization (WHO). The exclusion criteria were: to present speech disorders that made communication and/or understanding difficult between the researcher and the researcher; be a student enrolled in disciplines taught by researchers during the period of information production; and be a student enrolled in disciplines that the academics, members of the research team, were enrolled in during the information collection period.

The information was produced from October to December 2016, through a semi-structured interview, with questions of identification and open questions related to same-sex relationship and mental health.

For the recruitment of the participants, the snowball technique was used, considered one of the methods of capturing individuals belonging to marginal and hidden populations, as well as persons who experience same-sex relationships. The idea underlying this method is that subjects are selected from the existing social network among members of a sample. ${ }^{11}$ 
A representative of an LGBTI association indicated a participant from each of the educational institutions scenario of the study. After the interview with the first participant of each institution, they indicated the subsequent participants, and so on, until saturation of the information occurred. The interviews lasted from fifteen minutes to one hour and thirty minutes.

The information was interpreted following the content analysis, composed of the steps of: Pre-analysis; Exploitation of the material and; Treatment of the obtained results and interpretation. ${ }^{12}$ The Pre-analysis consisted in the choice of the documents to be analyzed and in the resumption of the initial objectives of the search. Readings and re-readings of all the material collected in the participants' interviews and the initial organization of the reports were carried out, aiming to have an overview of what was said by them and to perceive the particularities. The exploration of the material allowed us to understand the relevance among the speeches of each participant, to classify the central ideas and to organize them into two categories: 1) Discovery and acceptance of same-sex relationship; and, 2) Relationship with family, friends and society. In the last stage, of the treatment of the results obtained and interpretation, was elaborated an interpretative synthesis of the categories, allowing the dialogue between the themes, the objectives and the theoretical foundation.

It should be noted that all the ethical aspects contained in resolution 466/2012, of the National Health Council, were respected. The Informed Consent Form was presented to the participants and signed after acceptance of participation in the research. Their identities were preserved by the illustration of the speeches with the letter "l" of "Interview" and order number, after each excerpt. The present study was approved by the Research with Human Beings Ethics Committee of UDESC, under opinion number 1,777,561 / 2016.

\section{RESULTS}

Of the study participants, 12 are men and seven, women, ranging in age from 18 years to 23 years. Everyone said that they did not work, they only attended the University. Regarding the courses, the majority (15) was a student of Nursing; the others mentioned studying Social Sciences, Languages, Computer Science and Mathematics.

Next, the two categories that emerged from the interviews with the participants are presented and subsequently discussed.

\section{Discovery and acceptance of same-sex relationship}

Young people stated that they were built during their early childhood life as heterosexual people and, feeling different, when they realized their homosexual orientation, they began to wonder. For them, this encounter with themselves had an initial doubt, especially when confronted with cultural and moral issues from the family group.

I was built as a hetero-affective individual. [...] / always felt different, I could never meet the established standards, so
I became suspicious, why am I different? Why can't I feel the same as the male guy next to me? (E15)

Do you know when you always knew you were was different? My parents wanted a boy, [...] they could not understand that I was a girl, [...] they dressed me like a boy. I had the perception that I was a girl when I was 13 and my friend said: are you bisexual? [...] / started to cry because, deep down, I knew I liked my little friends. [...] had no intimacy with anyone to speak such an important thing (E6).

The relation between homoaffectives and the fear of revealing oneself, associated with respect for parents and their religious culture, is recurrent. Young people express the process of discovery and relationships with situations of restraint and repression experienced in childhood or adolescence.

I began to realize that I had same-sex attraction when I was 13 years old. I'm from a religious family, Catholic [...] you end up thinking: I have to do something to not be it [...] I met a colleague and we started a relationship, but I did not accept that it was homosexual. [...] as much as I knew and liked, I could not accept, in respect to my parents. (E13)

As a child, I felt something different for my friends, which was not normal, and I bent my knees, because the religion was very strong, and asked God to take it because it was the devil and I did not want this, I did not accept it! (E18)

In the process of self-acceptance of same-sex relationships, young people awaken to questions that contradict right and wrong, learned socially and morally, generating internal conflicts that lead to deconstructions. They point out that the lack of acceptance impairs their mental health, permeated by yearnings, denial, resistance and insecurity; and involves learning to deal with everyday confrontations.

I think the most difficult thing is acceptance of yourself, which affects your mental health a lot. [...] you are the spit, the rejected, and you internalize it, because I am this way, I internalize things a lot and it harms me. (E10)

[...] you get used to fighting prejudice, because you suffer so much that sometimes you think: I am not willing to discuss this, trying to deconstruct it, because it will be no use, it's the same as me wanting to talk to a wall and make it understand what I'm going through [...] I may be homosexual, but I cannot seem homosexual, I have to be hidden, because it's a shame for society, you start becoming afraid of some situations. (E16) 
Time has shown to be important in self-acceptance of samesex relationships, because through it occur events that favor the maturation of the individual and the encounter with other people. In this process of discovering and accepting same-sex relationships, the role of mother and friends stands out, offering security and comfort.

The part that really tightened up was when I was in the self-acceptance phase, but after I accepted myself, I already felt good about me [...] she [mother] said that regardless of anything, you are my son and I love you, I will not change with you because of this. It relieved me a lot [...] she was the way she always was: helpful, caring, worried; and that was a security I had. [...] I started to openly accept myself to people, this is no longer a problem for me. (E9)

What I suffered most was for me to accept [...] My mother knew, she said 'I always knew'. I did not suffer much until today because my mother helped me. My friends knew, it was very easy to talk to them, and here at the University, most of them are [homosexuals] and accept this peacefully $[\ldots](\mathrm{E} 6)$

\section{Relationship with family, friends and society}

The study participants reported the daily life experienced after this break with isolation, especially in the family environment. Young people with traditional families, with strict norms, did not dialogue with parents about their same-sex relationships due to the fear of being rejected, facing situations of violence, losing financial support or causing disagreements between father and mother. At times, it calls attention to their need to assume a parallel life, acting at home, as if they were other people, which results in unhappiness. The solution found to experience samesex relationships was sometimes to move away from the family.

My family is traditional [...] the dialogue with my parents has always been restricted, [...] to speak of same-sex relationships, never [...] I think they know, you end up being different from everybody, bit by bit you end up giving clues. (E15)

[...] oppression in the family all the time, [...] I never had the courage to tell them, even though I realize that they know, but I think they prefer that I do not say, [...] then I took a college entrance exam, I had no idea what I wanted to do, I simply wanted to leave the house [...] I turned away from them that way, and I left. (E4)

I'm not assumed for my family, it makes me have to be someone else in my house [...] pretending to be a person who is not, as if you made a theater in your life [...] / did not I have a conversation with my mother, there I have my refuges, one of them is the drink, I go after drinking to feel happy, because I know that if I assumed myself for my family, they could put me to out of the house [...] I do not have the courage to come and say, 'Mom, I like girls, I respect your opinion about it, but I wanted you to accept me', because I know a weight would come out of my shoulders and I could be happy, because I do not consider myself a totally happy person, not because I am homosexual but because I have distanced myself from the family. (E18)

The young people interviewed expressed the non-acceptance of the relatives about their same-sex relationships. They mentioned the search for professionals for psychic treatment, religious leaderships for benediction, attitudes of repudiation and reactions of shame or disappointment. Although a family crisis occurred, in some cases, the relationship with the family was resumed later. The speeches also demonstrated the difficulty of family members, especially members of the nuclear family, in coping with frustration in the breakdown of social expectations deposited in the young homosexual, leaving heartaches that are incorporated by him.

When I assumed myself, my mother would take me to the psychologist, the church and the pastor had to bless. (E17)

My mother went on hunger strike and stopped talking to me for two months, she was locked in the bedroom. She only cried, to her it was a mistake of hers me to become a lesbian [...] that made me very bad [...] one day my father said "you're acting like your daughter died, if you do not want to talk to the world or if you do not want to accept, ignore this part, but you cannot cut off the relation with her" [...] from that moment we were stared talking, there began a construction, both she and my sister, although accepting also, does not agree. (E14)

My father died [...] and it was something the family charged me, as if I had to replace my father, I would have to play a man role and, because I was gay, I was not a man. [...] I am very sorry about my sister, for several things she has already done, which she said, [...] she is ashamed to have a fag brother [...] (E19)

It was a thump, the male son, who he imagined would be a mechanic or work in the field. [...] I suffered a lot of prejudice at home [...] by names like: faggot, pansy. [...] this certainly left me marks, which will be taken. [...] I have not lived with my parents for three years, since when I said that I was homosexual, I do not have a good day anymore, we have lunch together, but there is no conversation at all. [...] (E16) 
In relation to the circles of friends, the people in same-sex relationships expressed about the confrontation, from the school period of situations of bullying, fears and physical aggressions. They reported that they go through the insecurity of telling about their homoaffectivity to a colleague and suffer reprisals or, even, lose the friendship. As they move through the school stage, they seek to make new friends, and these are important elements of the social support network that help them in their day to day difficulties.

\section{My classmates were making fun of me, calling me faggot, queer. (E17)}

I was the first to get to school and the last to leave, I let everyone out first. I already got beat, because, from a very early age I did not like to play ball, I did not feel comfortable in any group of boys [...] I already got beaten up because I did not want to play ball, because I did not play well, I got beaten in a locker room, in the entrance hall [...] (E1)

I have psychological counseling with my friends every day, because I think this network of friendship is a network that you can hold on to, you know it's friends, now, maybe people who do not have these friends that I have or maybe have other friends who do not have these perceptions are bound to suffer much more. (E16)

The results reveal a tendency for those in same-sex relationships to be labeled and judged superficially by society, punished with biased looks, laughter, cursing, jokes, criticism of the way they dress or behave, and attempted rape. This makes silence, often, a means of defense.

When you go out on the street, people give you a judging look, they drive around with their cars honking, screaming, joking, $[\ldots]$

when I got here I wanted to get free, living in another city, alone, and then I went to buy heels [...] you noticed the indignant saleswomen looking, with that ugly face and these things bother people. (E4)

[...] one night I came home quite late [...] and went to the bathroom, left the door open, and when I came back, there was a person inside my room. It was an attempted rape [...] I managed to get rid of him, but it was horrible, so much that it took me a long time to have my first relationship, I'm insecure, suspicious of everything, sometimes I'm quiet, because for me silence sometimes is the best answer. (E15)
There is prominence for the prejudices that they experience in the Universities coming from the teachers, who see same-sex relationships as problem and, sometimes, they pressure the homoaffective students to "be somebody who they are not".

Teachers were entitled to discuss whether or not a person could use the ladies' room, whether or not you could smooch in a library [...] these are people who have a study [...] what is the problem? Is the problem them being two people of the same sex? (E16)

I have a lot of signs [...] for the teachers that bothers, they keep asking a lot of me concerning the posture [...] When I go to the internship, the teachers want me to be a straight, which I'm not [...] it's difficult, because it's a charging, you cannot be what you are. (E19)

There were participants who reported that their experiences involving conflicting family relationships, prejudice and violence caused psychic suffering. Some reports have reported situations of eating disorders, depressive symptoms and suicide attempts.

For you to be gay you must have a very strong psychological because the whole time you are being overwhelmed. For example, when I go out on the street with my boyfriend, man! It's a honk, an ugly face, it's fagot, it's all the time people judging, it affects so much our psychological, in our house, our relationships. (E5)

I did not want to be like this, in the society that we live today. I started creating this barrier [...] I kept going away, in that I had several problems, there was a time that I had bulimia, anorexia, that I felt fat, and the boys did not come after me, I wanted to follow the hetero path. I started to isolate myself from people and it all kept me away from my family, to the point that I tried suicide. (E18)

\section{DISCUSSION}

In problematizing notions such as the universal right to health and integral care, in the context of the current health policies, especially in relation to people who are on the margins of a given social order, mental health is perceived as an essential element in determining the health-sickness process. An important implication of this concept is that mental health is more than the absence of mental disorders, it is a state of well-being in which the person realizes his/her own abilities, can deal with the daily tensions of life, work productively and is able to make contributions to the community. Mental health is fundamental to people's collective and individual capacity to think, to move, to interact with one another, to enjoy life and to be happy. ${ }^{13}$ 
The promotion, protection, and restoration of mental health are vital concerns of individuals, communities, and societies throughout the world. Therefore, practices that interfere with the determinants of mental health are important. Multiple social, psychological and biological factors interfere with a person's mental health, among them cultural aspects, moral, rapid social changes, gender discrimination and sexual orientation, social exclusion, risk of violence and violation of rights. Thus, considering the current concept of health promotion within $\mathrm{PHC}$, attention to culture and individual behaviors, with emphasis on the shared re-signification of life and its projects, are essential to combat the medicalizing tendency, sometimes, blameful and unfriendly which is in effect in the context of health care, nowadays.

The affections that emerge from the speeches of the young who are in same-sex relationships express that, in their trajectory, they go through several situations that interfere in their mental health. Initially, due to internal conflict, in the process of discovery and acceptance of sexual orientation. Subsequently, in the face of confrontations with family, friends, the university environment and society in general.

The study revealed that young people discovered their sexual orientation in adolescence, a phase that is permeated and characterized by intense changes and discoveries involving social, historical and cultural situations, which contribute to the transformation of individuals who seek an identity, including sexual identity, and their place in the world. In this search, sexuality reveals itself as a constituent element of the development and adolescing process. ${ }^{3}$ However, there is still no maturity to face the process of finding and accepting same-sex relationships. ${ }^{14}$

The event of discovering and accepting same-sex relationships is difficult for the individual, since, the sexual orientation itself is inserted in a context of relations immersed in beliefs, taboos and social constructions. Some speeches illustrate how gender stereotypes can interfere with the life of the young homosexual who cannot fit into society's standardized behavior patterns for men and women.

Young people have revealed feelings they have experienced and faced from discovering their sexual orientation, such as fear, guilt, repression and the feeling of being different and even feeling like someone else. The consequences for the health of these individuals are also revealed in another study conducted with young homosexuals. In a convergent way, fear and guilt were highlighted as feelings that emerge because they feel different and also because of the rejection and prejudice of family and society, towards the same-sex relationships. This situation makes young people vulnerable and may lead them to deny their desires, to self-punishment and to illness. ${ }^{14}$

The feelings expressed by the participants reveal that the individual can internalize the negative attitudes and values of society. This internalized homophobia has detrimental effects on mental health since it affects self-esteem and the development of a positive self-concept, which may result in self-flagellation or violence between individuals. ${ }^{15}$ In this direction, the importance of reflection on aspects involving deconstruction of hetero- normativity. It is necessary to widen the focus of the vision, to understand same-sex relationships, and to re-signify possible family conflicts and difficulties regarding the acceptance of their sexual orientation. ${ }^{16}$

Studies have shown that the timing of the disclosure of same-sex relationships to other people depends on the current circumstances of the homosexual person's life, the social environment, or the personal value given to revelation. When dealing specifically with the family, this disclosure has exclusive considerations related to individual and family characteristics. ${ }^{7,17}$ It is observed in the reports of the young that the family is their main source of social and economic support, however, revelation about their sexual orientation can be hampered by the fear of losing these supports, of abandonment and of not having the affection of the family anymore, as well as to protect it from social stigma.

Some young people reported that they did not talk to their families about this, but they realized that they already knew about their sexual orientation. However, because of lack of knowledge, because they do not know how to deal with the situation or because the truth is accompanied by the need for a position, many parents and relatives do not mention the subject until this is inevitable. ${ }^{18}$ In the speeches, a common attitude among young homosexuals is observed, to expend significant effort in the attempt to hide their sexual orientation in anticipation of the disapproval of others or due to fear of violence and discrimination. ${ }^{7}$

Research on the initiative to expose sexual orientation to the family has shown that disclosure usually happens when the homosexual person has a greater sense of connection with family members or perceives them as protectors. On the other hand, disclosure does not always occur if he, or she, predict violent or abusive family responses to the disclosure. ${ }^{7}$

Of the young people interviewed, those who took the decision and the initiative to reveal their sexual orientation to the relatives declared that this attitude caused conflicts, sufferings, and frustrations to the relatives because the homoaffectivity ends up leaving the standard of sexuality imposed culturally by the society, heterosexuality. The experiences of these young people confirm previous studies, referring to the difficulties encountered by people in same-sex relationships when they need to talk about their sexual orientation with relatives. ${ }^{7,14,18}$

The difficulty of family acceptance is related to several aspects. One of them is the fact that many individuals still consider same-sex relationships as a perversion or a mental disorder, and some, especially in the case of gays, associate it with AIDS. ${ }^{1}$ This logic of thought can be observed in the discourses of the young when they expressed about the attitude of the mother who sought the cure of the child through religion or treatment with professionals. ${ }^{14}$

Another aspect that contributes to the non-acceptance of same-sex relationships by family members is the beliefs common to traditional ideas, with a focus on the concept of procreation. In some cultures, parents consider their children's marriages as their responsibility and actively encourage, help, and even 
force their children to marry. Many homosexual couples engage in heterosexual marriages because, on the one hand, they are anxious to have children; on the other hand, wish to meet their parents' expectations. ${ }^{1}$

The concept of procreation is sometimes related to conceptions of a religious nature. In some religious institutions, individuals with homosexual orientation are perceived as mismatched by nature. Such institutions impose on the family sole responsibility for procreation and disregard same-sex relationships as if they are incapable of forming a family, have children, and lead a decent life. ${ }^{17} \mathrm{~A}$ study warns that religious groups that advocate the need for a change in sexual behavior and the healing of the homosexually oriented person are an important focus of change; because insofar as they spread these conceptions, it maintains prejudices and acts of discrimination. ${ }^{16}$

It is noteworthy that in this study, despite the initial reaction of the family after the revelation of the young about their sexual orientation, mainly fathers and mothers, demonstrated latter acceptance of the same-sex relationships of their children, with the resumption of relations. In a survey ${ }^{14}$, carried out with the young homoaffectives, it was observed that some families, even having difficulty understanding homosexuality, respected the young person's way of being. Another study ${ }^{18}$, which investigated three couples in same-sex relationships, showed that one of the couples reached the acceptance of all family members concerning their relationship. Of the remaining couples, one received partial acceptance, since some relatives continued to refuse, and another had only a limited number of relatives who dealt well with the issue. ${ }^{18}$

In the speeches of the participants of the study, bullying appeared in the life trajectory of the young who were in same-sex relationships since very early. The interviewees portrayed that they were discriminated in the school environment and suffered physical aggression in the locker rooms and in other school environments because they presented personal characteristics that differ from those of the heterosexual people. Scholars say that school is sometimes an entity that provokes violence, with educators unprepared for the construction of ideas of genders and social roles, and which in some way also practice forms of violence..$^{19}$ Violence oppresses, curtails freedom, prevents the young person from exercising his sexuality with freedom, from fighting for his rights and for his projects of happiness that are directly related to his acceptance and acceptance by the other, family and society.

In the perceptions of the young in same-sex relationships, there are biased teachers, who discriminate and intimidate them. They position themselves as oppressors, reproving young people for their behavior and their traits. They point out that, in some situations, teachers charge them heterosexual postures when they are attending classes in the nursing course, in a practical field. In this regard, young people protest and understand that they could not represent (in the sense of pretending) someone who they are not.
It is inferred from these experiences that it is necessary to talk about gender, sexuality and diversity issues in the spaces of the formation of individuals, with more openness and free of judgments. Spaces such as the University and the health service of the public network are favorable for discussing topics such as homosexuality and prejudice, involving professionals, students, teachers, and users. In addition to the search for scientific evidence, teachers are also responsible for problematizing the best practices in nursing, which include respecting the culture of collectivities, inclusion, and non-discrimination, informing and training on differences, respecting and protecting students from violence and exclusion, with a view to mutual respect and social justice.

Thus, it is essential to highlight the importance of nursing, which, through care for the individual, in the different life cycles, and the family, especially in the context of PHC, can make use of successful strategies in this approach. The promotion of health requires educational and empowering actions, meeting the unique needs, with a view to autonomy for a happy life. ${ }^{20}$ Through actions of this size, it can also approach itself and create adequate means for dialogue on issues such as sexuality and sexual orientation, involving the discovery, self-acceptance, acceptance of the family and society. ${ }^{14}$

In this line, it is opportune to consider the Policy of Integral Assistance to the health of the population of Lesbian, Gay, Bisexual, Transvestite, Transsexual - LGBT and the National Policy of Basic Attention, that has been acting in the logic of cultural competence, signaling to the universality of access to health services and actions, prohibition of exclusion based on age, gender, race/color, ethnicity, belief, nationality, sexual orientation, gender identity, among others. ${ }^{21}$

There is also, from a programmatic perspective, an important reflection to be carried out, which concerns the implementation of the 2013-2020 Mental Health Action Plan approved by WHO. It combines universality and targeted interventions for health promotion, prevention of mental disorders, reduction of stigmatization, discrimination and human rights violations; and which is responsive to the specificities of vulnerable groups. A specificity in relation to the goals of this plan is to reduce the suicide rate by implementing health promotion and prevention strategies, including suicide and self-harm prevention. ${ }^{22}$

It is evident that, as in other conditions of vulnerability, many problems related to the mental health of young homosexuals are the result of the reaction of social groups in which traverse people who deviate from culturally acceptable standards. The selfbuilding, deconstructing, rebuilding are common movements in the process of living. However, tolerance and respect for diversity are virtues in which its absence permeates the feelings and the construction as individuals of the young people who participated in this study. In this direction, it is considered opportune to provoke the debate, from this and other research on the subject, on the reorganization of nursing curricula (having ethics as transversal content) and services (adhering to health promotion actions, with emphasis on cultural competence). 


\section{CONCLUSIONS AND IMPLICATIONS FOR PRACTICE}

The experiences and feelings expressed by the young people who participated in the research show that in their life course and in their socio-cultural environment there is a context of oppression, stigma and violence related to non-recognition and lack of acceptance of sexual diversity. They present, in a subjective way, psychic sufferings, resulting from prejudices, heteronormative rules, stigmas, seclusion, loss and loneliness that compromise their mental health. As a result, some young people think of suicide, which deserves the attention of health services and professionals, especially nurses, as this is a serious public health problem.

It seems quite beneficial to think that the most diverse situations through which young homosexuals pass can be configured as learning situations for parents, teachers, nurses and society in general. Getting rid of prejudices, looking at the different with respect, being open to dialogue in the different spaces of mental health production, are complex and essential skills for PHC professionals, so they need to be developed and improved, based on evidence, considering cultural aspects and the different needs of users and collectivities.

As a limitation of the study, it is recognized that family, friends and educators living with young who are in same-sex relationships were not investigated, which is important information to know affective, cultural and social elements from the perspective of these individuals, in order to produce new knowledge about the subject. Further studies are recommended in other scenarios to deepen and evaluate other aspects related to same-sex relationships, with a view to subsidizing actions aimed at health promotion and sexual diversity, including the training of health professionals to work with this public, in the exercise of family mediation and other social segments.

\section{REFERENCES}

1. YuY, Xiao S. Health and life satisfaction for Chinese gay men in Guangzhou, China. J Cent South Univ (Med Sci) [Internet]. 2017 Dec; [cited 2018 Jul 23]; 42(12):1407-16. Available from: http://www.csumed.org/xbwk/fileup/ PDF/2017121407.pdf

2. Sattler FA, Franke GH, Christiansen H. Mental health differences between German gay and bisexual men and population-based controls. BMC Psychiatry [Internet]. 2017 Jul; [cited 2018 Jul 23]; 17:277. Available from: https://www.ncbi.nlm.nih.gov/pmc/articles/PMC5521135/ pdf/12888_2017_Article_1435.pdf

3. Natarelli TRP, Braga IF, Oliveira WA, Silva MAI. O impacto da homofobia na saúde do adolescente. Esc Anna Nery [Internet]. 2015 Oct/Dec; [cited 2018 Jul 24]; 19(4):664-70. Available from: http://www.scielo.br/pdf/ean/ v19n4/1414-8145-ean-19-04-0664.pd

4. Tomicic A, Gálvez C, Quiroz C, Martínez C, Fontbona J, Rodríguez J, et al. Suicidio en poblaciones lesbiana, gay, bisexual y trans: Revisión sistemática de una década de investigación (2004-2014). Rev Med Chile [Internet]. 2016; [cited 2018 Jul 23]; 144:723-33. Available from: http://www. revistamedicadechile.cl/ojs/index.php/rmedica/article/viewFile/4475/2168
5. Yi H, Lee H, Park J, Choi B, Kim SS. Health disparities between lesbian, gay, and bisexual adults and the general population in South Korea: Rainbow Connection Project I. Epidemiol Health [Internet] 2017 Oct; [cited 2018 Jul 23]; 39:e2017046. Available from: https:// www.ncbi.nlm.nih.gov/pubmed/29056030

6. Lee C, Oliffe JL, Kelly MT, Ferlatte O. Depression and suicidality in gay men: Implications for health care providers. Am J Mens Health [Internet]. 2017 Jul; [cited 2018 Jul 23]; 11(4):910-9. Available from: https://www.ncbi.nlm.nih.gov/pmc/articles/PMC5675322/ pdf/10.1177_1557988316685492.pdf

7. White Y, Sandfort T, Morgan K, Carpenter K, Pierre R. Family relationships and sexual orientation disclosure to family by gay and bisexual men in Jamaica. Int J Sex Health [Internet]. 2016 Sep; [cited $2018 \mathrm{Jul} 23$ ]; 28(4):306-17. Available from: https://www.ncbi. nlm.nih.gov/pmc/articles/PMC5325687/pdf/nihms814326.pdf

8. Mgopa LR, Mbwambo J, Likindikoki S, Pallangyo P. Violence and depression among men who have sex with men in Tanzania. BMC Psychiatry [Internet]. 2017 Aug; [cited 2018 Jul 23]; 15;17(1):296. Available from: https://www.ncbi.nlm.nih.gov/pmc/articles/ PMC5558659/pdf/12888_2017_Article_1456.pdf

9. Bränström R, Pachankis JE. Sexual orientation disparities in the cooccurrence of substance use and psychological distress: a nationa population-based study (2008-2015). Soc Psychiatry Psychiatr Epidemiol [Internet]. 2018 Apr; [cited 2018 Jul 23]; 53(4):403-12. Available from: https://www.ncbi.nlm.nih.gov/pubmed/29450600

10. Bastos GG, Garcia DA, Souza LMA. A homofobia em discurso: Direitos Humanos em circulação. Ling (Dis)curso [Internet]. 2017 Jan/Apr; [cited 2018 ul 23]; 17(1):11-24. Available from: http://www. scielo.br/pdf/ld/v17n1/1518-7632-ld-17-01-00011.pdf

11. Wright R, Stein M. Snowball sampling. In: Kempf-Leonard K, ed Encyclopedia of social measurement. New York (NY): Elsevier; 2005. p. 495-500.

12. Bardin L. Análise de conteúdo. São Paulo: Edições 70; 2011.

13. Nações Unidas no Brasil. Saúde mental depende de bem-estar físico e social, diz OMS em dia mundial. Brasília: ONUBR; 2016. [cited 2018 Oct 28]. Available from: https://nacoesunidas.org/ saude-mental-depende-de-bem-estar-fisico-e-social-diz-oms-emdia-mundial/

14. Zanatta EA, Ferraz L, Klein ML, Marques LC, Ferraz L. Descobrir, aceitar e assumir a homoafetividade: situações de vulnerabilidade entre jovens. Rev Fund Care Online [Internet]. 2018 Apr/Jun; [cited 2018 Jul 23]; 10(2):391-8. Available from: http://www.seer.unirio.br/ index.php/cuidadofundamental/article/view/6058/pdf_1

15. Blondeel K, Vasconcelos S, García-Moreno C, Stephenson R, Temmerman M, Toskin I. Violence motivated by perception of sexual orientation and gender identity: a systematic review. Bull World Health Organ [Internet]. 2018 Jan; [cited 2018 Jul 23]; 96(1):2941. Available from: https://www.ncbi.nlm.nih.gov/pmc/articles/ PMC5791869/pdf/BLT.17.197251.pdf

16. Silva MML, Frutuozo JFF, Feijó MR, Valerio NI, Chaves UH. Família e orientação sexual: dificuldades na aceitação da homossexualidade masculina. Temas Psicol [Internet]. 2015 Sep; [cited 2018 Jul 24]; 23(3):677-92. Available from: http://pepsic.bvsalud.org/pdf/tp/v23n3/ v23n3a12.pdf

17. Costa CB, Machado MR, Wagner MF. Percepções do homossexual masculino: sociedade, família e amizades. Temas Psicol [Internet] 2015 Sep; [citet 2018 Jul 23]; 23(3):777-88. Available from: http:// pepsic.bvsalud.org/pdf/tp/v23n3/v23n3a20.pdf

18. Sanches IR, Pelissoli MS, Lomando EM, Levandowski DC. Rede de apoio social de famílias homoafetivas formadas por mulheres. Gerais Rev Interinst Psicol [Internet]. 2017 Jul/Dec; [cited 2018 Jul 23]; 10(2):176-93. Available from: http://pepsic.bvsalud.org/pdf/ gerais/v10n2/04.pdf 
19. Fernandes H, Oliveira EM, Ventura RN, Horta ALM, Daspett C. Violência e vulnerabilidade ao HIV/AIDS em jovens homossexuais e bissexuais. Acta Paul Enferm [Internet].2017 Jul/Aug;[cited 2018 Jul 29];30(4):390-6. Available from: http://www.scielo.br/scielo.php?script=sci_arttext\&pid=S010321002017000400390\&lng=en

20. Oliveira CLC.Apontamentos teórico-conceituais sobre processos avaliativos considerando as múltiplas dimensões da gestão do cuidado em saúde. Interface (Botucatu) [Internet].2011 Apr/Jun; [cited 2018 Aug 5]; 15(37):58999. Available from: http://www.scielo.br/pdf/icse/v15n37/a21v15n37.pdf
21. Ministério da Saúde (BR). Portaria № 2.436, de 21 de setembro de 2017 (BR). Aprova a Política Nacional de Atenção Básica, estabelecendo a revisão de diretrizes para a organização da Atenção Básica, no âmbito do Sistema Único de Saúde (SUS). Brasília (DF): Ministério da Saúde; 2017.

22. World Health Organization - WHO. Mental Health Atlas 2017 [Internet]. Geneva:World Health Organization; 2018. [cited 2018 Oct 28]. Available from: http://www.who.int/mental_health/evidence/atlas/mental_health_ atlas_2017/en/ 